ARTICLE

Received 7 Feb 2017 | Accepted 25 May 2017 | Published 4 Jul 2017

DOI: $10.1057 /$ palcomms.2017.56

OPEN

\title{
Race and surveillance in the settler colony: the case of Israeli rule over Palestine
}

\author{
Ronit Lentin ${ }^{1}$
}

ABSTRACT This article begins by outlining a three-pronged critical theory of the state of Israel as, following Giorgio Agamben, a state of exception, following David Theo Goldberg, a racial state, and, following Patrick Wolfe, a settler colony. Elia Zureik's work on the role of surveillance used by the state of Israel in controlling the Palestinians both in Israel proper and in the territory occupied by Israel in 1967 is then outlined. Since theories of exception and settler colonialism often fail to specifically foreground race, the paper continues by following African American theorist Alexander Weheliye who critiques westocentric work on exception and biopolitics as not foregrounding race, placing race front and centre in this analysis of Israel's war against the Palestinians. Following Zureik's work on the centrality of surveillance to Israel's racialized settler-colonial control of Palestine and its citizens, occupied and exiled populations and Agamben's insistence that the line separating citizens and non-citizens is very thin indeed (2008), the article focuses on the extension of strategies of surveillance to Israel's critics, including Israeli Jews, international critics and diaspora Jewish people. In conclusion, the article focuses on Israel's highly funded surveillance campaign against supporters of the Boycott, Divestment and Sanctions campaign, to demonstrate the crucial role played by discourses of security and practices of information gathering and harassment in maintaining what Patrick Wolfe has termed the Israeli settler colony's "logic of elimination", which, as he argued in his last book, is highly racialized. This paper is published as part of a collection on racism in counter-terrorism and surveillance discourse.

\footnotetext{
${ }^{1}$ Trinity College Dublin, Dublin, Ireland Correspondence: (e-mail: rlentin@tcd.ie)
} 


\section{Introduction}

n December 2016 Israel's Minister for Education Naftali Bennet announced a plan to lay down new ethical guidelines for Israeli academics. This is the latest in a long line of initiatives by the leader of the right wing "Jewish Home" party, aimed at making Israel's higher education institutions "more loyal to the State of Israel". The initiative follows the Minister prohibiting school visits by the Israeli whistle blower group "Breaking the Silence-Israeli Soldiers Talk about the Occupied Territories" (http://www.breakingthesilence.org.il/ (accessed 25 January 2017)) (Adamkar, 2017), reprimanding teachers who criticize the Israeli Defence Forces (IDF), and removing a novel depicting a Jewish-Palestinian love story from the secondary school literature syllabus. The proposed guidelines on academic conduct are particularly sinister because the man charged by the Minister to draft them is none other than philosophy professor Asa Kasher who is also the author of the IDF's ethics guidelines (Roth, 2016).

Kasher came to international attention in the wake of Israel's 2014 assault on Gaza in which 2,251 Gazans (70 per cent of them civilians, including 551 children and 299 women) were killed (http://gaza.ochaopt.org/2015/06/key-figures-on-the-2014-hostili ties/ (accessed 17 May 2017)), when he acknowledged that the IDF had acted on his preference for putting the lives of Israeli soldiers above those of "their" civilians, expressing his satisfaction with the IDF's conduct during the carnage that left the Gaza Strip in ruins and thousands wounded and homeless. Although Kasher is an award winning academic and a member of countless associations, including the Jerusalem Ethics Centre and the Israeli Institute of Democracy, and although he has been praised for "keeping a close watch on our national moral compass" (http://www.israelhayom.com/site/newsletter_article.php?id $=4804$ (accessed 27 January 2017)), putting the author of the IDF's ethics code in charge of watching over Israel's higher education institutions is hugely problematic. Asking "what enables Asa Kasher", Israeli philosopher Anat Matar (2016) questions his fitness to serve as Israel's conscience, even though she does not focus on the high level of surveillance such guidelines would necessitate.

This article begins with a critical and tentative outlining of a three-pronged theory of the State of Israel as firstly, state of exception (Agamben, 2005), secondly, a racial state (Goldberg, 2002, 2009), and thirdly, a settler colony (Wolfe, 2006). However, since theories of exception and settler colonialism often fail to foreground race, I follow the African American theorist Alexander Weheliye (2014) who critiques westocentric work on exception and biopolitics by placing race front and centre of my analysis of Israel's permanent $\operatorname{war}^{1}$ against the Palestinians.

Following Zureik (2016), the article then focuses on the role of surveillance as used by the Israeli racial settler colony in controlling Israel's Palestinian citizens, occupied and besieged subjects, but also Israeli and Jewish dissidents, as the measures taken by Minister Bennett, as well as a variety of recent legal initiatives demonstrate. Considering Agamben's insistence (2008) that the line separating citizens and non-citizens is very thin indeed, the article concludes by outlining the extension of strategies of surveillance to Israel's critics, including Israeli citizens and international critics, with particular reference to the highly funded surveillance against supporters of the Boycott, Divestment and Sanctions (BDS) campaign.

The article aims to insert race into the analysis of the Israeli settler colony through a critique of what I consider Eurocentric theorizations by Israeli scholars (for example, Ilan Pappe and Oren Yiftachel) who focus their theorization of the Israeli state on ethnicity rather than race, as well as white European scholars such as Giorgio Agamben whose otherwise useful theoretical intervention stops short at foregrounding race in analysing what are patently racial conditions and who employs the Nazi concentration camp regime as his yardstick while occluding coloniality, settler colonialism and decolonization.

Is Israel a racial state of exception? In view of the escalation of Israel's permanent war against the Palestinians, an escalation constituting a cynical development in the history of Israel's ongoing policies of colonization, oppression, occupation and siege, I begin by setting out the theoretical context for critically engaging with Israel's rule over Palestine as first, a state of exception (Agamben, 2005), second, a racial state (Goldberg, 2002, 2009), and third, a settler colony (Wolfe, 2006, 2016).

Governed through a complex web of emergency legislation, and through practices of exception, emergency, necessity and security and a discourse of Jewish victimhood, the State of Israel may arguably be theorized as a textbook example of what the Italian political philosopher Giorgio Agamben's (2005) calls “state of exception", in the sense of both état and condition. In Israel/ Palestine the state of exception involves both the extension of military wartime powers into the civil sphere, and the suspension of constitutional norms that protect individual liberties (Zreik, 2008)..$^{2}$ In Homo Sacer: Sovereign Power and Bare Life (1995) Agamben (rather curiously) follows the Nazi theorist Carl Schmitt in arguing that the state of exception renders the lives of specific population groups "bare life", both excluded from and captured within the political order. Agamben also builds on Foucault (2003) theorizing racism as marking a caesura between what must live and what must die.

I argue that Israeli governmental technologies construct racialized categories through population management measures of segregation and exclusion, from the 1948 Zionist "Plan D" for what the Israeli historian Ilan Pappe (2006) problematically called "the ethnic cleansing of Palestine", to ongoing occupation policies in the Palestinian territory conquered by Israel in 1967, and the prevention of the return of Palestinian refugees expelled during and after the $1948 \mathrm{Nakba}^{3}$ The Israeli political geographer Oren Yiftachel (2016) likens the racial categorization of citizenship in Palestine/Israel to South African Apartheid: Jews he regards as "white" citizens, Arab citizens of Israel as having "coloured" (partial) citizenship, and Palestinians in the occupied territory as having "black" citizenship, without political rights.

Using the term "ethnicity" in the Israeli context is, however, rather problematic. ${ }^{4}$ Pappe's by now ubiquitous term "ethnic cleansing", originally coined in relation to the 1990s Bosnian war, to describe the 1948 Zionist conquest of Palestine, constructs both Israeli Jews and Palestinian Arabs as homogeneous ethnic groups despite their obvious ethnic heterogeneities. Likewise, Yiftachel's view of Israel as "ethnocracy" (2006) also assumes ethnic homogeneity. Both analyses occlude race in the Palestine-Israel context, despite Gilmore's (2007) argument that categorizations and classifications-both central to the Zionist rule over Palestine as this article argues-are at once the pre requisite and the consequence of racial dehumanization.

Indeed Israel is awash with dehumanizing racial classifications including of Palestinian citizens, Palestinian occupied and besieged subjects and diasporic Palestinians, many of whom have been living in refugee camps since the 1948 Nakba. Racial classifications also abound among Palestinian citizens: thus, for instance, more than half of the approximately 160,000 Naqab Bedouin citizens of Israel live in "unrecognized villages", to which the state refuses to provide a planning structure and the most basic services including water, electricity, roads and schools, and which the state demolishes on a regular basis, aiming to transfer the Bedouins to government-built urban centres (http://www.acri. 
org.il/en/category/arab-citizens-of-israel/negev-bedouins-andunrecognized-villages/ (accessed 25 January 2017)). Intra-Jewish ethnic heterogeneities-between white European-Ashkenazy and black Arab-Mizrahi as well as Ethiopian Jews also amount to racial classifications, though it is the racial segregation between Israeli Jews and Palestinian Arabs that ultimately enables Israel to ensure that Jewish settlers in the Occupied Palestinian Territory (OPT), but also Jewish Israelis living in occupied 1948 Palestine, a.k.a. the State of Israel, live at the expense of the Palestinian others, or, as Foucault (2003: 255) describes it, establishing "a relationship between my life and the death of the other".

These classifications affirm Israel's control over Palestinian citizens and occupied subjects by both the security services and the civil authorities, involving ongoing practices of surveillance by the Israeli Security Agency (Shabak), ${ }^{5}$ regular raids of Palestinian villages and homes, checkpoints and the separation wall, curfews, house and village demolitions, population transfers, widespread arrests and administrative detention, the detention and torture of Palestinian minors, and culminating in increasing numbers of extrajudicial executions, all of which render the Palestinians subject to, as well as the object of Israeli sovereignty.

Because Agamben's theory occludes the explicit deployment of race, conceptualizing Israel as state of exception must be coupled with theorizing it as a racial state that excludes and includes in order to construct homogeneity, which, however, according to Goldberg (2002: 16), is "heterogeneity in denial". Race, Goldberg insists, is imposed upon otherness: "it is only through the racial configuration of the external, of the other... that the internal-the self-becomes racially defined" (2002: 23). Paradoxically, however, once racially configured, the other becomes a threat that the state must contain and control.

The task of homogenization, containment and control is achieved through various governmental technologies including citizenship regimes, border controls and census categorizations, but also invented histories and traditions that construct state memory, ceremonies and cultural imaginings, and the evocation of ancient (in Israel's instance Biblical) origins. In imagining Israel as "Europe away from Europe", Zionism - the brain child of Central and Eastern European, mostly socialist atheist Jews who nonetheless mobilized Biblical promises and the Jewish religion to their cause-created a racial state par excellence. Exception here becomes the rule and the constant state of emergency enables one rule (life) for the state's Jewish citizens (as well as Jewish people from around the world who are entitled to citizenship upon immigration to Israel), and another (death, threat of death, threat of expulsion) for the state's Palestinian and other non-Jewish subjects, not entitled to citizenship and whose lives are rendered "bare" (Shenhav, 2006). Goldberg (2009: 139) calls this "racial Palestinianization": "Palestinians are treated not as if a racial group, not simply in the manner of a racial group, but as a despised and demonic racial group".

Zionism, Goldberg writes, is about the modernizing imperative according to which Jews (though ancient Biblical people) are modern, while Palestinians are pre-modern and thus in need of Zionism's civilizing-but always also colonizing-mission. Paradoxically, however, for a people whose history is replete with racial persecutions, Zionist ideology itself articulates "the Jewish race", constructing a homogeneous "Jewish people" despite obvious Jewish ethnic and religious heterogeneities (Sand, 2009), with Jewish self- and other racialization an integral part of Zionist ideology and practice. Falk (2006) reads the history of Zionism as a eugenic race project, aiming to save the Jewish genetic pool from the degeneration resulting from diaspora existence. Antisemitism racialized Jews as a separate "race" whose persecution was justified by biological reasoning while Zionist ideologues, who adopted the terminology of volk-a racial nation shaped by "blood and soil", were instrumental in producing a Zionist repertoire of racial categorization and volkish imagery.

This race thinking is responsible for Israel's racial citizenship and immigration regime that privileges the "ingathering of (Jewish) exiles" on the strength of The Law of Return. Enacted in 1950, this law, based on Orthodox Judaism, applies to people with a Jewish mother or maternal grandmother, later changed-in response to Israel's demographic anxiety following the 197 occupation of the West Bank, the Gaza Strip and the Golan Heights (Wolfe, 2016) to apply to those with one Jewish grandparent $^{6}$ (Hayeem, 2010). Jewish immigrants are granted jus sanguinis citizenship and generous financial and social benefits and tax exemptions with the imperative of ensuring Israel's Jewish majority. Conversely, the seven million Palestinian refugees (http://imeu.net/news/article0038.shtml, (accessed 27 January 2017)) are denied the right of return to their homes and lands-a right recognized by UN resolution 194, the Geneva Convention, and the Universal Declaration of Human Rights (Hayeem, 2010). The 160,000 Palestinians who remained in the territory conquered by the Zionists in 1948 were dubbed "Israeli Arabs", deprived of their Palestinian identity, and put under a Military Government regime, based on the 1945 British Mandate Defence (Emergency) Regulations, which abolished basic rights of expression, movement, organization and equality, though they left Palestinian citizens the right to vote and be elected.

While Agamben's state of exception might be read as based on suspending the law by placing his homo sacer outside the law, I argue, after Goldberg (2002), that the law, far from being merely suspended, actually works in the service of the racial state. As Goldberg argues: "racial states... are bound by necessity to legal expression... (and) have taken themselves to be conceived and constituted, managed and maintained through the rule of law". Law, he insists, serves the "national fantasy of homogeneity" and, with particular reference to settler colonial states, the "logic of legality mediated racio-national alienation... in their drive to state formation" (Goldberg, 2002: 139-40). Despite its idealized claims to fairness, the law reduces people to mere objects, constructs racial categorizations and classifications.

Israel is no exception in this regard. Examples of Israel's racial laws include, beside the 1950 Law of Return, the Law for Absentee Property (1950) that grants the state ownership of the property of Palestinians expelled and expropriated during and after the 1948 Nakba, and deemed "present absentees"; and the Jewish National Fund Law (1953), which charged the JNF, a land purchasing agency, with administering public land in Israel, including large tracts of displaced Palestinians' lands (http://www.badil.org/en/almajdal/item/1404-mahajneh-jnf-and-israeli-law (accessed 15 January 2017)), barring the selling, leasing, sub-letting and owning of land by "non-Jews", read Palestinians. Moreover, in 1960 Israel established the Israel Land Authority that controls 93 per cent of Israeli land as "public domain; that is, either property of the state, the JNF or the Development Authority (DA)," on behalf of the so-called "Jewish nation", leading to just seven per cent of the land being owned by Israel's Palestinian citizens (http://www. globalresearch.ca/israel-s-discriminatory-land-policies/14579 (accessed 28 January 2017)).

Adalah, the Legal Centre for Arab Minority Rights in Israel, lists 50 Israeli laws that racially discriminate against Palestinian citizens of Israel in all areas of life, including rights to political participation, access to land, education, state budget resources, and criminal procedures. Some laws specifically violate the rights of Palestinians living in the 1967 Occupied Palestinian Territory and of Palestinian refugees. The laws exclude Palestinians "from the land; turn their citizenship from a right into a conditional privilege; limit the ability of Arab citizens and their parliamentary representatives to participate in the political life of the country; 
criminalize political acts or speech that question the Jewish or Zionist nature of the state; and privilege Jewish citizens in the allocation of state resources" (Adalah, 2012). The latest addition to Israel's racial legislation is the controversial nation-state bill, which holds that Israel is "the national home of the Jewish people" and that the right to realize self-determination in the state is unique to them. It further revokes Arabic as an official language, though "its speakers have the right to languageaccessible state services" (Lis, 2017a). While the bill does not subordinate democracy to the state's Jewish character, as did an earlier version, legal scholar Aeyal Gross argues, again referring to ethnicity rather than race, that the bill is undemocratic as "linking self-determination and the state's identification with a certain ethnic group within it, at the expense of others' equality and sense of belonging, is not anchored in the law or practice of democratic countries" (Gross, 2017).

Besides curtailing the access of Israel's Palestinian citizens to land resources, these laws often overturn Supreme Court decisions that accord them any civil rights, stifle freedoms of association and expression, discriminate on the basis of national belonging, and support criminal indictments and punitive measures instigated by the Knesset against its elected Arab members.

All this means that the Israeli racial state anchors the discrimination against Palestinian citizens, occupied and besieged subjects in a racialized legal framework. At the same time Israel also puts itself above and beyond international law, arguably making it a state of exception par excellence. Exploring the legality of the continued Israeli occupation of the Palestinian territory, Ben-Naftali et al. (2005) go beyond examining Israel abdicating its duties as an occupying power and focus on the legality of the occupation itself, which they regard as an illegal state of exception that blurs the boundaries between the normal order of sovereign equality between states and the exception (that is, occupation).

Webb-Pullman (2013) further argues that "whilst Israel has ratified the main human rights conventions, Israel is not party to most Optional Protocols... nor has it accepted the jurisdiction of any of the treaty body committees, which means that relevant committees cannot receive or act on complaints or claims against Israel' including the widespread use of torture". This unilateral exemption means not only that Israel is a state of exception par excellence, but, on a more material level, that Israeli governmentalities such as administrative detention without trial, detention of minors, torture, house and village demolitions, population transfers and extrajudicial executions go without control or censure by international law, constituting it as a racialized state of exception.

Deconstructing exception: Israeli settler colonialism. While useful to theorizing Israeli exceptionalism that positions the state above and outside domestic and international law as far as Palestinian citizens and occupied and besieged subjects are concerned, Agamben's theory of the state of exception has been critiqued for its author's Eurocentric approach and lack of attention to colonialism and settler colonialism (Svirsky and Bignall, 2012; Wolfe, 2016). This is why I complement Agamben's and Goldberg's analyses by theorizing Israel as a settler colonial project (for example, Wolfe, 2006,2016), the main objective of which is not the exploitation of the natives, but rather access to their territory.

Defining Israel as settler colonial goes against the Zionist movement's self-image as a just response to European antisemitism that enabled the settlement of a "people without land" in "a land without people", 7 even though it colonized an already settled territory and explicitly cast itself in settler colonial terms. Thus
"Yishuv"-the name of the pre-state polity in Palestine-literally means "settlement" in Hebrew, and early Zionist ideologues spoke openly of "Jewish colonies" replacing existing Palestinian villages and urban neighbourhoods (Benvenisti, 2002: 263).

Unlike colonialism which is about the exploitation of the natives, settler colonialism is about replacing the natives, and it always replaces what it destroys. In Palestine this meant Zionists replacing Palestinian orchards with imported European conifers (which they dubbed "making the desert bloom"), depopulated Palestinian villages and urban neighbourhood with Jewish settlements, roads and national parks, Palestinian place names with Hebrew place names, and the present day campaign of replacing Bedouin villages, deemed "unrecognized", with space for Jews-only urban and rural settlements, army manoeuvres, and green spaces-classic settler colonial governmentalities.

Informed by various interpretations of terra nullius (a land without people), settler colonialism is a land-centred project. Wolfe theorizes settler colonialism as premised on securing territory in terms of "structured genocide", evidenced by the expulsion of 800,000 Palestinians from their lands during and after the 1948 Nakba, by the 1967 occupation of the West Bank, Gaza, Sinai and the Golan, by progressively dispensing with Palestinian workers from the occupied territory, and by the increasing military and civil control of the occupied territory. A poignant example is the building of the so-called "separation wall", that, as Wolfe argues, is a concrete expression of spatial sequestration, making Palestinians more and more dispensable and Gaza and the West Bank more and more like reservations and ghettos (Wolfe, 2006: 404).

Unlike colonials, settler colonials come to stay, asserting sovereignty by Western law in "a logic of elimination", that aims not to destroy but to produce life, so as to amalgamate indigenous peoples, cultures and lands into the body of the settler nation (Morgensen, 2011). Thus, as Zionist settler colonials stayed on and regarded the new colony as "their" land given to them by divine promise, they had to exercise control and surveillance of the life practices of the indigenous Palestinians, to enable the Jewish colonists to live at the expense of the Palestinian natives.

Wolfe notes that Agamben's deeply entrenched eurocentrism prevented him from seeing the colonial context, focusing instead on the centrality of the paradigm of security in the state of exception, which uses security as "the normal technique of government" (Agamben, 2005). Indeed, discourses of security, "existential threat" and Jewish victimhood are central to Israel's racial policies. While it sees itself as a haven for the "Jewish nation", Israel regards the control of 1948 Palestinians, 1967 Palestinians and diasporic Palestinians as an imperative born of necessity and emergency, which, Agamben suggests, creates and guarantees the situation that the law needs for its validity.

Israel's settler colonial regime creates constant zones of exception, as witnessed inter alia in the 2014 massacre of Gaza, conceived as exterior to any considerations of humanity. One example of exception is the separate military courts system for trying occupied Palestinians, including many minors, "operating with virtually no transparency, subject to very lax internal supervision, and rarely exposed to any public scrutiny" (Yesh Din, 2013). Another illustration of settler colonial exception is the occupation's colonial bureaucracy and permit regime enacted every day in every West Bank checkpoint (Berda, 2012).

\section{Critiquing bare life: From settler colonialism to racial assemblages}

Racism is the ordinary means through which dehumanization achieves ideological normality, while, at the same time, 
the practice of dehumanizing people produces racial categories... This culture, in turn, is based on the modern secular state's dependence on classification, combined with militarism as a means through which classification maintains coherence (Gilmore, 2007: 243-244).

- Theorizing Israel as a racial state of exception appears to make sense but has to be used critically, "under erasure". In Agamben and Colonialism, Svirsky and Bignall (2012) critique Agamben's project for being firmly anchored in Western political thought, being conceived without reference to colonialism and anticolonialism, and for ignoring the critical interventions by colonized people engaged in acts of decolonization, although, like Agamben, they do not privilege race. Therefore, following Goldberg's "racial Palestinianization” (2009), Wolfe's theorizing colonialism's 'racial traces', and Weheliye's (2014) critique of Agamben's lack of attention to 'racialized assemblages' I posit race as central to analyzing Israel's settler colonial rule over the Palestinians,

Weheliye's main point of criticism of Agamben's and Foucault's westocentric theories of exception, bare life and biopolitics is that they are universally transportable precisely because they don't speak from an explicitly racialized standpoint, and do not consider political violence as socio-political processes of differentiation and hierarchization projected onto the human body. Such processes, I propose, are employed by the State of Israel in racializing citizen, occupied, besieged and diasporic Palestinian subjects, even though few analyses of Israeli settler colonialism privilege race, despite the obvious racial differentiations between Jewish Israeli humans, complicit not-quite-human Palestinian citizens denigrated as "Israeli Arabs", and finally, non-human, or dehumanized, occupied, besieged and refugee Palestinians as well as Bedouin citizens living in "unrecognized villages". As Gilmore (2007: 244) points out, the Israeli state depends on racial classifications, which it combines with militarism as a means through which classification maintains coherence.

In his posthumous book, Wolfe posits races as traces of colonial history that reproduce relationships of inequality as central to his understanding of settler colonialism: "Racialization represents a response to the crisis occasioned when colonizers are threatened with the requirement to share social space with the colonized" (Wolfe, 2016: 14). As hierarchies and exceptions must be maintained, the task of homogenizing is left to the colonizers. And, Wolfe reminds us, to homogenize is to divide, leaving the white colonizers to do the ruling.

Wolfe's invoking race in theorizing settler colonialism leads me to Weheliye's critique of Agamben's Eurocentric theories of exception and bare life as based primarily on the Nazi extermination camps, without giving credence to their colonial antecedents (such as the ignored German colonization of Namibia and the genocide of the Herreros, see Zimmerer, 2005). In Homo Sacer (1995) Agamben paradoxically posits the Muselmann (a term used for concentration camp inmates who reached rock bottom, and who were thus named because, totally deplete of life force, they crouched as if in Muslim prayer) as transcending race, even though this is an explicitly racial category referring to Muslims. Agamben's analysis, Weheliye argues, rests on the unseeing of racializing assemblages. Weheliye's black studies standpoint, hugely relevant in analyzing Palestine, insists that as humans create race for the benefit of some and to the detriment of other humans, as Wolfe demonstrates in his analysis of settler colonialism, employing the Nazi camps to explicate race is not only Eurocentric but also theoretically inadequate.

Weheliye cites African American feminist theorist Hortense Spillers (2003), who argues that the racializing assemblages of the middle passage, plantation slavery, and Jim Crowe, not included in most conceptualizations of the biopolitical nomos of modernity, highlight how routine the brutalization of black flesh continues to be in the world of (Western) Man. Spillers writes that black flesh was routinely created by "the calculated work of iron, whips, chains, knives, the canine patrol, the bullet". Likewise, I propose, contrary to Israel claiming the need to fight against "Palestinian terrorism", in Israel's oppressive war against the Palestinians Palestinian flesh is routinely created by the calculated work of sponge, rubber and metal bullets, tear gas, riot control equipment, air bombardments and ground offensives, military court systems, torture, jails, administrative detention, home and village demolitions, checkpoints, the separation wall, and extrajudicial executions. These practices, I maintain, are a direct result of racializing the Palestinians as a lesser people whose right to their lands is refuted and denied by the settlercolonials. The grammar and practice of racializing Palestinian flesh illustrate not only the routine rather than exceptional logic of the Israeli racial settler colony. They also demonstrate that Eurocentric theorizations of exception and bare life are ultimately inadequate to understanding the embodied centrality of race in the context of Palestine-Israel, manifesting in surveillance and control technologies of categorization, hierarchization, population transfers and extensive demolitions, and extending to Israel's illegal settlement policies. These surveillance and control mechanisms were introduced by the Zionist settler colonials long before the establishment of the State of Israel through taking over Palestinian lands before, during and after the Nakba, and negating Palestinian rights.

And Israeli settler colonialism continues as the long history of expropriating Bedouin Palestinian lands attests. Writing about the expulsion of Bedouins from Rafah (part of the Gaza Strip) in the early 1970s, and in the context of the January 2017 brutal demolition of the "unrecognized" Bedouin village Umm Al-Hiran to enable the construction of a religious Zionist settlement, ${ }^{8}$ Israeli blogger Idan Landau posits racism as the only reason for their expulsion:

The architects of the expulsion coveted the Bedouins' lands. I use the term 'racist' because a non-racist settlement policy would have seen no contradiction between the Bedouins staying on their lands and the establishment of Jewish settlements. The insistence on expelling the Arab inhabitants of the land... as a precondition of Jewish settlement exposes the inherently racist aspect of the Zionist project (Landau, 2017).

Importantly, to construct racial hierarchies and achieve high levels of racial segregation, it is vital for the racial settler colony to employ constant surveillance technologies, as I now discuss.

\section{Race, settler colonialism and surveillance}

Surveillance is based on the gaze of otherness. A key feature of surveillance in colonized regions is its racialization of the native (Zureik, 2016: 95).

Palestinian sociologist Elia Zureik posits the colony as a laboratory for developing and testing surveillance technologies and argues that surveillance is a key feature of colonialism and settler colonialism. In Israel, he insists, military surveillance technologies including census taking, map making, and racial profiling (as well as enlisting Palestinian collaborators through a complex system of threats and rewards exercised by the Israeli Security Agency, see Cohen, 2010) have proven successful in 
controlling the Palestinian population and putting down Palestinian opposition.

Surveillance technologies had originated in colonial settings and a key surveillance technology-the panopticon-was a colonial invention, developed on Europe's colonial frontier with the Ottoman Empire. As Mitchell (1988: 35) argues, "examples of the panopticon were built for the most part not in northern Europe, but in places like colonial India". In fact the British transferred surveillance mechanisms such as identity cards, map making and census categorizations from India to Palestine during the Arab revolt of 1936-1939 to stave off Arab opposition to colonial rule and to illegal Zionist immigration (Zureik, 2016: 98-9). Zureik cites Khalili (2013) who argues that the difference between Israel and other colonial settings is Israel's use of encirclement and enclavization of vast terrains. These terrains are easier to control through the use of carceral mechanisms such as watchtowers and security fences that the British had used to cope with the Arab revolt and that the Israelis have developed and still use to police the occupation of Palestine. Here the main instrument of surveillance and control is the separation wall, used not only to prevent and monitor the passage of people between Palestinian towns, villages, hospitals, schools, universities and other work places, but also, as Bowman (2003: 129) insists, to put the Palestinians beyond the sight of the Israeli Jewish population -both settlers and citizens-through a Jews-only road system. It is worth noting that the wall-the main instrument of segregation and surveillance-has led to the expropriation of 10 per cent of West Bank Palestinian lands (Zureik, 2016: 99).

Beside physical means of surveillance such as the separation wall, checkpoints and watch towers, employed to control the movements of the occupied Palestinian population, the State of Israel has been using other methods of surveillance ever since its establishment. Zureik notes the centrality for colonial rule of the surveillance technology of statistics, that Foucault (2009: 100) termed "science of state". Colonial rule employed statistics to construct classification criteria of land, population, and other forms of record keeping that have serious implications for governing dispossessed populations. Statistics, Zureik reminds us, have the power to "make up" people, and the use of the population census by the Israeli state in "making up" the Palestinians under its rule is no exception. According to Leibler (2011), the first Israeli census in 1948 excluded some of the Palestinians who remained in the territory after the Nakba and who were consequently not counted as citizens. To this day Palestinians who were absent for census purposes in 1948 are labelled "present absentees" whose property and lands were taken over by the Custodian for Absentee Property governed by a 63year-old law which allows Israel to confiscate "absentee" properties of Palestinian-owned homes, sending a dangerous message and arguably putting up a road block to peace (Prusher, 2013). In some cases the descendants of these "present absentees" continue to reside in "unrecognized" localities with no access to their original homes. The 1967 census in the occupied West Bank and Gaza repeated the 1948 exercise by undercounting the resident populations of the occupied territory and denying the right of return to Palestinian residents who were absent from their homes on census day for study, work or travel purposes. Furthermore, Palestinians from the West Bank and the Gaza Strip displaced during the fighting who had not returned home in time for the census, or were residing abroad, were not registered. In addition to the 800,000 Palestinians displaced during the Nakba, the 1967 war displaced a further 900,000 Palestinians, according to the United Nations Relief and Works Agency for Palestine (UNRWA) (Zureik, 2016: 102).

In colonial settings census categorizations always involve identity construction, enabling census and population data to be sorted and labelled to reflect the wishes and needs of the colonial sovereign. Moreover, in the Israeli case, like in the British one, colonial rule cannot be executed by records alone and needs local power through the appointment of village leaders, the distribution of favours and the use of threats to recruit collaborators. As Cohen (2010) documents for the 1948-1967 period, the State of Israel employed tight surveillance in order to construct an "Arab-Israeli identity" and conversely erase the Palestinian identity by recruiting a network of Palestinian collaborators who kept an eye on (and reported to the Israeli authorities) Palestinians who criticized the state and engaged in acts of resistance. The main arenas the collaborators worked in were schools; pupils reported teachers who spoke about the refugees' right of return, teachers reported their colleagues who criticized the 1948-1966 Military Government regime, head teachers reported their pupils: "the main aim was to make people feel that the authorities" eyes and ears were wide open, to create anxiety, to silence. And "the new Arab" - the Israeli Arab-was supposed to be born from that silence" (Cohen, 2010: 13). And Cohen reminds us that this constant state surveillance was supported by some Palestinian public figures who served as the authorities' eyes and ears in their own communities.

This state of affairs prevailed during the early years of the state and supports Zureik's (2016: 103) argument that as liberalism justifies the treatment of natives as an inferior group in terms of values, rationality and claims to the land, colonial governmentalities often rule from a distance employing information gathering through local informers, census taking and mapping of the national territory. Berda (2012) argues that colonial surveillance signifies a shift from controlling the territory to managing the population. The creation of dual and separate legal systems, a civilian court system for the colonizer, and a military court system for the colonized, is another definite feature of surveillance and control by the colonial administration (Shenhav and Berda, 2009).

Maps are another crucial tool of surveillance, indoctrination and hegemony, particularly when used to project the past and describe the present so as to inculcate the young in the values of the colonizer. Maps structure our views of reality and engender the territory rather than merely reflecting it (Zureik, 2016: 103). Map making has been a cornerstone of the Zionist settler colonial project as an instrument of claiming the colonized territory as the settlers' Biblical home. Pappe (2006) writes that already in the early 1900s the Jewish National Fund-the agency charged with buying Palestinian lands to facilitate the colonization of Palestine - created a detailed registry of all Arab villages with the explicit aim of "greatly helping the redemption of the land" (emphasis added). The result was the "village files", an archive completed in the late 1930s, which facilitated the 1948 Zionist takeover of Palestine. The "village file" included a topographic recording of the village layout, a survey of the village's "Hebraic origins" if any (as part of the Zionists' claim to ownership of what they considered their "promised land"), aerial photographs of each village, and a detailed map of each village to include its location, access, roads, land quality, water springs, main sources of income, socio-political composition, religious affiliations, names of mukhtars, ${ }^{9}$ relationships with other villages, ages of individual men, and, importantly, an index of the villagers' hostility or otherwise towards the Zionist project. The last items fuelled "the worst atrocities in the villages, leading to mass executions and torture" (Pappe, 2006: 17-19).

Maps are surveillance tools both in staking colonial claims and in resisting them. According to a 2013 report Victims of our Own Narratives? Portrayal of the "Other" in Israeli and Palestinian School Books, 76 per cent of Israeli schools' textbook maps show no boundary between the occupied Palestinian territory and 
Israel, and Palestinian areas are not labelled. These maps are presented as maps of Israel, and "the absence of borders between Israel and Palestine can be seen as implying that the Palestinian areas are part of the state of Israel". On the Palestinian side, only 4 per cent of maps in Palestinian textbooks show the green line that separates the Palestinian territory from Israel or label the area west of the OPT as "Israel"-demonstrating that colonial maps can also be resisted by the colonized through map making (Sherwood, 2013).

Zureik (2016: 108-109) argues that in colonial settings the rationale for surveillance is guided by exclusion through restrictions of mobility and access. As a settler colonial occupying power, Israel, he insists, is interested less in the management of the population and its wellbeing than in controlling, excluding and appropriating the territory in which the population resides. At the same time the colonial power is interested in controlling data collection and categorization which is why identity documentation is used as another instrument of surveillance.

Palestinians, Zureik writes, say they are most fearful about having their identity cards confiscated, as without them they are under constant threat of expulsion or loss of residency rights. Indeed identity cards are double edged swords: they facilitate the monitoring of the occupied population, who are liable to be expelled without them. In Israel mandatory identity cards carrying citizens' racial affiliations were introduced in 1949. Until 2002 identity card holders were classified as "Jewish", "Arab" or "Druze", since, because of the Zionist insistence on the Jewish nature of the state, "Israeli' nationality per se does not exist and is thus not recorded in internal Israeli identity documents, despite numerous legal appeals calling upon the state to replace religious with nationality affiliations_-staking religion as a racial marker. In 2002 the identity cards carrying racial affiliations were replaced with biometric cards cross-referencing government data bases. However, in the occupied Palestinian territory colour coded identity cards differentiate between population groups according to status, enabling the state to police Palestinian subjects and monitor their movements: Palestinian residents of East Jerusalem (blue identity cards with the prefix 08); Palestinian residing in the occupied Palestinian territory (orange cards with the prefix 09); Palestinian offspring of an East Jerusalemite and a non-resident (prefix 086). Furthermore, since 2002 Israeli law prohibits family reunification of West Bank and Gaza residents if they marry Israeli residents and are males under 35 or females under 25 (Halabi, 2011).

Crucially, in the occupied Palestinian territory identity cards are products of three political environments: Israeli administrative and military rule, the 1993 Oslo Accords that transferred the day to day running of the territory to the Palestinian Authority that issues its own ID cards, and the East Jerusalem system which, as detailed above, issues identity cards in different colours to different categories of Palestinian residents. Thus identity cards become primary instruments of racialization and surveillance, facilitating the granting or withholding of permits and controlling the movement of Palestinians within the occupied territory, where they become essential tools in Israel's matrix of control, regulating mobility and residency, albeit not bestowing citizenship rights, in keeping with Israel's racialized citizenship regime. As Tawil-Souri (2011: 220, cited in Zureik, 2016: 111) suggests, the identity card regime provides a "low-tech, visible, physical and tactile" means of colonial power.

Another sinister technology of controlling dissent both within the State of Israel and in the occupied Palestinian territory is the surveillance of social media use. Thus during the 2014 Israeli assault of the Gaza enclave hundreds of Palestinians were fired from their jobs because of negative social media comments about the Gaza attack. According to Israeli Palestinian
Knesset member Ahmad Tibi, "Almost all Arabs of the 1948 areas who have written anything against the Israeli assault on Gaza on their Facebook pages have been summoned by the Israeli security authorities for investigation and interrogations" (Nazzal, 2014).

The surveillance of Palestinians' social media use continues. A 2016 report by the Palestinian Center for Development and Media Freedoms (MADA) (http://www.madacenter.org/news. php?lang $=18$ id $=288 \#$ (accessed 1 February 2017)) details several prosecutions of Palestinian journalists, indicating excessive surveillance leading to preemptive arrests, interrogation and detention for social media posts expressing political opinions seen as "inciting resistance". In collusion with the Israeli authorities, Facebook administrators have removed the accounts of managers and journalists of the Shahab Network and Al Quds News Network that together have a following of over 12 million users (ISM Palestine, 2016).

Perhaps the most notorious case of social media surveillance is the arrest of the Palestinian poet, photographer and activist Dareen Tatour because of a 2015 Facebook status she published during a wave of popular struggle by the Palestinians, in Jerusalem and throughout Gaza, the West Bank and within the State of Israel itself. The main reason for indicting Tatour was a poem she posted on Youtube titled "Resist my people, resist them". According to the Israeli political activist Yoav Haifawi, "there is nothing illegal in this poem, not even according to Israel's laws. But the context matters, as the poem came out against a backdrop of Palestinian youths clashing with the occupation forces. And the images of these, according to the Israeli prosecution and media, are of 'Palestinians engaged in terrorist activity' " (Haifawi, 2016). Tatour, a citizens of Israel, has been under arrest and house arrest since October 2015, and despite appeals by hundreds of international writers and activists, at the time of writing she remains under house arrest, must wear an electronic ankle bracelet and is prohibited from using the internet (http://imemc.org/article/dareen-tatours-prosecutionfor-poetry-continues-in-nazareth-court/ (accessed 1 February 2017)).

Ever since the pre-1948 "village files", racializing surveillance technologies have been used by the Israeli settler colony mostly against the indigenous Palestinians. However, in recent years, with the growing international support for the Palestinian struggle, Israel has cast its surveillance net more widely, targeting dissident Israeli and diaspora Jews, as well as international supporters of Palestine in general and of the BDS campaign in particular.

\section{Conclusion: From subject to citizen}

"Boycotts for political reasons are a legitimate tool that falls under the protection of freedom of political expression" (Haaretz editorial, January 17 2017). This was written following the Knesset Interior and Environment Committee's approval of ... a bill that would prohibit the granting of entry visas or residency permits to foreign nationals who call for a boycott of Israel or the settlements. Therefore, I invoke the authoritative statement by Haaretz to call upon Israeli citizens who belong to the peace camp to appeal to the international community to impose a boycott on Israel (Hammerman, 2017)

While all Israeli higher education institutions and most Israeli academics collaborate with the government by conducting research upholding rather than criticizing the state, as well as research and development of armaments and security equipment, offering tailor-made programmes for military and security 
personnel, and discriminating against Palestinian academics and students (Hever, 2009), the above quote by the leading Israeli intellectual Ilana Hammerman demonstrates that not all Israeli academics back the occupation and that some support boycotting Israel. The Israeli government fears such support and by early February 2017, soon after the initiative by Israel's Minister for Education to charge philosopher Asa Kasher with creating ethical guidelines for institutions of higher education, a bill was proposed in the Knesset that, if passed, would cut funds for Israeli universities that employ lecturers backing the academic boycott on Israel; I cannot begin to imagine the level of surveillance managing this would necessitate (Lis, 2017b).

In this article I put forward a three-pronged analysis of Israel's rule over Palestinian citizens, occupied and besieged subjects as, firstly, state of exception, secondly, racial state, and thirdly, settler colony. I went on to highlight the scant focus on the key issue of race in analyzing Israeli control and surveillance of Palestinian populations. I conclude by arguing that the focus of surveillance has shifted from being exclusively targeted at Israel's colonized subjects to also focusing on dissent by Israeli citizens and on criticism by diaspora Jews and the international community. According to Agamben (2008), the line dividing between refugee (as well as colonized and occupied subject) and citizen is very thin, as the control and surveillance measures exercised by Israel, and the series of laws enacted by the State of Israel in recent years against Israeli and Jewish dissidents and human rights organizations demonstrate.

Various laws have been enacted recently aiming to label Israeli, Jewish and international anti-occupation activists dissidents and potential terrorists. These laws include the so-called 2016 "NGO Law", meant to stigmatize Israeli left-wing and human rights organizations as agents of foreign powers by forcing them to publicly declare any foreign funding (Schaeffer Omer-Man, 2016); and the so-called "anti-Facebook bill" that would empower the courts to order social media providers like Facebook, Google, YouTube and Twitter to remove content Israel regards as endangering personal, public or state security (https://www. middleeastmonitor.com/20160713-israel-launches-anti-facebookbill/ (accessed 1 February 2017)).

The work of surveillance and racialization in the service of the racial settler colony is never done, as Israel portrays itself as victim while continuing the occupation and siege of Palestine and the discrimination against Palestinian citizens and Israeli dissidents. One poignant example are the state-funded surveillance strategies occasioned by the war Israel has explicitly declared on supporters of the BDS campaign. Here the role played by discourses of security and practices of information gathering and harassment is crucial to maintaining what Patrick Wolfe (2016) terms settler colonialism's "logic of elimination", which, as he argues, is highly racialized.

Israel's anti-BDS campaign, described by Prime Minister Netanyahu at an emergency BDS donors meeting in Las Vegas in June 2015 as a battle against delegitimizing Israel (http:// www.ynetnews.com/articles/0,7340,L-4665676,00.html (accessed 1 February 2017)), led to tasking Gilad Erdan, the minister for Strategic Affairs and Public Diplomacy, with fighting BDS, that he warned foreign ambassadors "should not be seen as a threat only to Israel... but as a threat to the international community, and to all who value human rights and freedoms" (Ahren, 2016).

The anti-BDS campaign, budgeted at 100 million Israeli Shekels (26.5 million dollars) has engendered a series of legal initiatives, demonstrating yet again the use of the law in the service of the racial state. In January 2017, based on surveillance of both citizens' and visitors' support for boycotting Israel, the Knesset Interior Committee initially approved a bill that would bar issuing entry visas and residency permits in Israel to foreign visitors who knowingly and publicly call for a boycott of Israel or the settlements, and to citizens who represent organizations that call for boycotting Israel, its institutions or territory under its control, namely the Jewish settlements in occupied Palestine (Lis, 2017c).

Agamben has written little about Israeli sovereignty as state of exception. He nonetheless provides a faint glimmer of hope in "Beyond human rights", in which he posits the potentialities of resistance, and of doing away with nation-states that, like settlercolonies, albeit using race and surveillance to differentiate between refugee, colonized subject and citizen, ultimately target all in the face of dissent as I have argued in this article. In 2008 , as he was writing his essay, " 425 Palestinians expelled by the State of Israel find themselves in a sort of a no-man's land. These people certainly constitute, according to Hannah Arendt's suggestion, 'the vanguard of their people'." Agamben, however, sees the exiled Palestinians neither as racialized subjects nor as the nucleus of a future Palestinian state. Instead he insists that "the no-man's land in which they are refugees has already started from this very moment to act back into the territory of the State of Israel by perforating it". He concludes by saying that "only in a world in which the spaces of states have been thus perforated and topologically deformed and in which the citizen has been able to recognize the refugee that he or she is-only in such a world is the political survival of humankind today thinkable" (Agamben, 2008: 95).

\section{Notes}

1 I owe the concept 'permanent war' to Jasbir Puar (see Mikdashi and Puar, 2016) 2 It is worth noting that Ilan Pappe rejects the theorization of Israel as state of exception, which he says applies only to democracies in decline, arguing that Israel is not a democracy judging by its unequal treatment of its Palestinian citizens and of occupied Palestinian subjects. Instead he proposed theorizing Israel as a 'mukhabarat' (intelligence) state of oppression (Pappe, 2008).

3 The Arabic term Nakba means catastrophe, the Palestinian term for what the Israelis call their 'War of Independence', see for example, Masalha (2012). During the Nakba 800,000 Palestinians were brutally uprooted, expelled, forced to flee or murdered in cold blood. In addition, 531 villages and 11 urban neighbourhoods in Tel-Aviv, Haifa, Jerusalem and other cities were destroyed and erased except in the collective memories of their inhabitants and descendants who continue to consider them their rightful homes (http://www.globalresearch.ca/israel-s-discriminatory-land-policies/14579, accessed 28 January 2017).

4 See Alana Lentin (2004: 74-75) on the substitution of 'race' with 'ethnicity' and 'racism' with 'cultural relativism' in the wake of the UNESCO post World War II 'world panel of experts' which resulted in the publication of the UNESCO Statement on Race and Racial Prejudice.

5 The Israeli Security Agency, established soon after the founding of the state, though legislated for only in 2002. Its wide ranging duties include safeguarding state security, interrogating terror suspects, providing intelligence for operations in the West Bank and the Gaza Strip, counter-espionage, personal protection of public figures and government buildings. All this gives it a central role in controlling the lives of occupied and besieged Palestinian populations (https://www.shabak.gov.il/english/Pages/default. aspx, accessed 30 January 2017).

6 Mainly to accommodate immigrants from the former Soviet Union in the 1990s, a large number of whom were not Jewish according to Orthodox Judaism but were admitted because they had Jewish relatives, so as to augment Israel's Jewish majority (Hayeem, 2010)

7 While in his seminal The Question of Palestine (1980: 9) Edward Said mistakenly attributes this slogan to the Zionist writer Israel Zangwill, it was actually used as early as 1843 by a Christian Restorationist clergyman (Garfinkle, 2009: 265).

8 According to a summary by Tarabut, Umm al Hiran's Bedouins had lived in Wadi Zubala from which they were removed in 1948 and several times later to facilitate the construction of Israeli settlements and, like other 'unrecognized' Bedouin villages, their homes are regularly being demolished by the Israeli security forces http://www.tarabut. info/he/articles/article/al-qian-umm-al-hiran/, accessed 31 January 2017).

9 Arabic for head of local government of a town or village.

\section{References}

Adalah (2012) New Discriminatory Laws and Bills in Israel. Adallah: Haifa. Adamkar Y (2017) The destruction of democracy: The 'Breaking the Silence' law unanimously approved by the Knesset, Walla 8 January, http://news.walla.co.il/ 
item/3029757?utm_source $=$ facebook\&utm_medium $=$ sharebutton\&utm term $=$ social\&utm_content $=$ facebook\&utm_campaign $=$ socialbutton, accessed 8 January 2017.

Agamben G (1995) Homo Sacer: Sovereign Power and Bare Life. Stanford University Press: Stanford, CA.

Agamben G (2005) State of Exception. University of Chicago Press: Chicago, IL London.

Agamben G (2008) 'Beyond human rights'. Social Engineering; 15, 90-95.

Ben-Naftali O, Gross AM and Michaeli K (2005) Illegal occupation: Framing the occupied Palestinian territory. Berkeley Journal of International Law; 23 (3): 551-614.

Ahren R (2016) Israeli minister calls BDS a danger to the whole world. Times of Israel 23 March, http://www.timesofisrael.com/minister-boycott-movement-athreat-to-the-whole-world/, accessed 1 February 2017.

Benvenisti M (ed) (2002) The Morning After: The Era of Peace - No Utopia. Carmel and Hebrew University: Jerusalem, Israel.

Berda Y (2012) The Bureaucracy of the Occupation: The Permit Regime in the West Bank, 2000-2006. The Van Leer Institute Hakibbutz Hameuchad Publishing House: Jerusalem, Israel.

Bowman G (2003) Israel's wall and the logic of encystization: Sovereignty exception or wild sovereignty? European Journal of Anthropology; 50, 127-137.

Cohen H (2010) Good Arabs: The Israeli Security Agencies and the Israeli Arabs 1948-1967. University of California Press: Oakland, CA.

Falk R (2006) Zionism and the Biology of the Jews. Resling: Tel Aviv, Israel.

Foucault M (2003) Society Must be Defended: Lectures at the College de France, 1975-76. Allen Lane: London.

Foucault M (2009) Security, Territory, Population, Lectures at the Collège de France 1977-1978. Palgrave MacMillan: Houndmills, UK.

Garfinkle A (2009) Jewcentricity: Why the Jews Are Praised, Blamed, and Used to Explain Just About Everything. John Wiley and Sons: London.

Gilmore RW (2007) Golden Gulag: Prison, Surplus, Crisis and Oppression in Globalizing California. University of California Press: Berkeley, CA.

Goldberg DT (2002) The Racial State. Blackwell: Oxford.

Goldberg DT (2009) The Threat of Race: Reflections on Racial Neoliberalism. Wiley-Blackwell: Malden, MA

Gross A (2017) Israel's nation-state bill is undemocratic. Haaretz 11 May http:// www.haaretz.com/opinion/.premium-1.788553, accessed 17 May 2017.

Haifawi Y (2016) Poetic injustice: Palestinian poet arrested over Facebook post. 972 Magazine, 17 April https://972mag.com/poetic-injustice-palestinian-poetarrested-over-facebook-post/118641/, accessed 1 February 2017.

Halabi U (2011) Legal analysis and critique of some surveillance methods used by Israel. In: Zureik E, Lyons D and Abi-Laban Y (eds). Surveillance and Control in Israel-Palestine: Population, Territory and Power. Routledge: London.

Hammerman I (2017) Why I, as a proud Israeli, want the world to boycott us. Haaretz 29 January http://www.haaretz.com/opinion/.premium-1.767900, accessed 30 January 2017.

Hayeem A (2010) Israel unfair law of return. The Guardian 11 March, https://www. theguardian.com/commentisfree/2010/mar/11/israel-return-jews-palestinians, (accessed 27 January 2017.

Hever S (2009) Academic Boycott of Israel and the Complicity of Israeli Academic Institutions in Occupation of Palestinian Territories. Alternative Information Centre: Jerusalem, Israel; Beit Sahur, http://www.alternativenews.org/, accessed 4 February 2017.

ISM Palestine. (2016) Surveillance, censorship and arrests of activists using social media in Palestine. 26 October https://monitor.civicus.org/newsfeed/2016/10/ 31/Surveillance-censorship-and-arrests-of-activists-using-social-media-in-Pales tine/, accessed 1 February 2017.

Khalili L (2013) Time in the Shadows: Confinement and Counterinsurgencies. Stanford University Press: Stanford, CA.

Landau I (2017) Rafah expulsion and the Zionist doctrine of unknowing. 26 January https://idanlandau.com/2017/01/26/rafah-expulsion-and-zionist-doctrine-of-unknowing/ (accessed 29 January 2017.

Leibler A (2011) "You must know your stock": Census as surveillance practice in 1948 and 1967. In: Zureik E, Lyons D and Abu-Laban Y (eds). Surveillance and Control in Israel/Palestine. Routledge: London.

Lentin A (2004) Racism and Anti-Racism in Europe. Pluto Press: London.

Lis Y (2017a) Israeli lawmakers back contentious Jewish Nation-State bill in heated preliminary vote. Haaretz 10 May http://www.haaretz.com/israel-news/1. 788393, accessed 17 May 2017.

Lis Y (2017b) Israeli bill would cut funds to universities with lecturers backing boycott. Haaretz 3 February http://www.haaretz.com/israel-news/.premium-1. 769255, accessed 4 February 2017.

Lis Y (2017c) Israel law makers move to ban settlement-boycott advocates from entering country Haaretz 12 January http://www.haaretz.com/israel-news/. premium-1.764528, accessed 1 February 2017.

Masalha N (2012) The Palestinian Nakba: Decolonising History, Narrating the Subaltern, Reclaiming Memory. Zed Books: London.

Matar A (2016) What enables Asa Kasher? www.wisdom.weizmann.ac.il/ oded/ PS/anat.doc, accessed 1 February 2017.
Mikdashi M and Puar JK (2016) Queer theory and permanent war. GLQ: A Journal of Lesbian and Gay Studies; 22 (2): 215-222.

Mitchell T (1988) Colonising Egypt. American University in Cairo Press: Cairo, Egypt.

Morgensen SL (2011) The biopolitics of settler colonialism: Right here, right now. Settler Colonial Studies; 1 (1): 52-75.

Nazzal N (2014) Palestinians targeted for social media use in Israel. Gulf News 24 July http://gulfnews.com/news/mena/palestine/palestinians-targeted-for-socialmedia-posts-in-israel-1.1363596, accessed 1 February 2017.

Pappe I (2006) The Ethnic Cleansing of Palestine. Oneworld Publications: Oxford

Pappe I (2008) The mukhabarat state of Israel: A state of oppression is not a state of exception. In: Lentin R (ed) Thinking Palestine. Zed Books: London.

Prusher I (2013) Israel's Absentee Property Law Exposes an Absence of Morality in Jerusalem. Haaretz 7 July http://www.haaretz.com/blogs/jerusalem-vivendi/. premium-1.528427, accessed 30 January 2017.

Roth N (2016) Former IDF ethicist tapped to censor 'political speech' in Israeli universities. 972 Magazine 9 December http://972mag.com/former-idf-ethicisttapped-to-censor-political-speech-in-israeli-universities/123600/, accessed 10 December 2016.

Said E (1980) The Question of Palestine. Times Books: New York.

Sand S (2009) The Invention of the Jewish People. Verso: London.

Schaeffer Omer-Man M (2016) How Israel is turning anti-occupation activists into dissidents. 972 Magazine 2 July http://972mag.com/how-israel-is-turning-antioccupation-activists-into-dissidents/120425/, accessed 31 January 2017.

Shenhav Y (2006) The imperial history of 'state of exception'. Theory and Criticism; 29, 205-218.

Shenhav Y, Berda Y (2009) The colonial foundations of the state of exception: Juxtaposing the Israeli occupation of the Palestinian territories with colonial bureaucratic history. In: Ophir A, Givoni M and Hanafi S (eds). The Power of Inclusive Exclusion: Anatomy of Israeli Rule in the Occupied Palestinian Territories. Zone: New York.

Sherwood H (2013) Israeli and Palestinian textbooks omit borders. The Guardian 4 February https://www.theguardian.com/world/2013/feb/04/israeli-palestiniantextbooks-borders, accessed 30 January 2017.

Spillers H (ed) (2003 [1987]) Mama's baby, Papa's maybe: An American grammar book. In: Black, White and in Color: Essays on American Literature and Culture. Chicago University Press: Chicago, IL.

Svirsky M and Bignall S (eds) (2012) Agamben and Colonialism. Edinburgh University Press: Edinburgh, UK.

Tawil-Souri H (2011) Orange, green and blue: Colour-coded paperwork for Palestinian population control. In: Zureik E, Lyons D and Abu-Laban Y (eds). Surveillance and Control in Israel/Palestine. Routledge: London.

Webb-Pullman J (2013) Israel: Immune or Impugnable? Palestinian Media Agency 26 March http://alray.ps/en//index.php?act = post\&id $=93 \# . V y 81-75 H N \_k$ accessed 15 January 2017.

Weheliye AG (2014) Habeas Viscus: Racializing Assemblages, Biopolitics and Black Feminist Theories of the Human. Duke University Press: Durham, NC; London.

Wolfe P (2006) Settler colonialism and the elimination of the native. Journal of Genocide Research; 8 (4): 387-409.

Wolfe P (2016) Traces of History: Elementary Structures of Race. Verso: London.

Yesh Din. (2013) Military Courts. http://www.yesh-din.org/cat.asp?catid =5, accessed 3 February 2-17.

Yiftachel O (2006) Ethnocracy: Land and Identity Politics in Israel/Palestine. University of Pennsylvania Press: Philadelphia, PA.

Yiftachel O (2016) Call apartheid Israel by its name. Haaretz, 11 February http:// www.haaretz.com/opinion/.premium-1.702597, accessed 18 January 2017.

Zimmerer J (2005) Annihilation in Africa: The 'race war' in German South West Africa (1904-1908) and its significance for a global history of genocide. GHI Bulettin; 37, 51-57.

Zreik R (2008) The persistence of the exception: Some remarks on the story of Issraeli constitutionalism. In: Lentin R (ed). Thinking Palestine. Zed Books: London.

Zureik E (2016) Israel's Colonial Project in Palestine: Brutal Pursuit. Routledge: London; New York.

\section{Data availability}

Data sharing is not applicable to this article as no datasets were analysed or generated.

\section{Additional information}

Competing interests: The author declares that there are no competing interests.

Reprints and permission information is available at http://www.palgrave-journals.com/ pal/authors/rights_and_permissions.html

How to cite this article: Lentin R (2017) Race and surveillance in the settler colony: the case of Israeli rule over Palestine. Palgrave Communications. 3:17056 doi: 10.1057/ palcomms.2017.56 
Publisher's note: Springer Nature remains neutral with regard to jurisdictional claims in published maps and institutional affiliations.

(c) (i) This work is licensed under a Creative Commons Attribution 4.0 (c) International License. The images or other third party material in this article are included in the article's Creative Commons license, unless indicated otherwise in the credit line; if the material is not included under the Creative Commons license, users will need to obtain permission from the license holder to reproduce the material. To view a copy of this license, visit http://creativecommons.org/licenses/by/4.0/

(C) The Author(s) 2017 